the two latter. In his second paper Prof. Wyville Thomson drew attention to peculiarities in the mode of propagation of certain Echinoderms of the Southern Sea. He passed in review examples of the Sea-cucumbers (Holothuroids), Sea Urchins (the circular Cidaroids, and heart-shaped, Spatangoids), Star-fish (Asteroids), and the Brittle Stars (Ophiuroids). In allusion to their phases of development he stated the majority of these pass from the egg without the intervention of a locomotive pseudembryo. Among other data in support of this view he said, that while in warm and temperate seas "plutei" and "bipinnari" were constantly taken in the surface-net; yet during the southern criise between the Cape of Good Hope and Australia, only one form of Echinoderm pseudembryo occurred, and which was considered with some little doubt as the larva of Chirodota from the presence of dermal, calcareous, wheel-shaped spicules: Furthermore Prof. Wyville Thomson described in detail the almost constant occurrence among the majority of the foregoing groups a curious, receptacular pouch wherein the young are carried until arriving at a certain maturity. This marsupium is situated on the dorsal portion of the body, is composed of a series of plates which meet centrally and permit of the young creeping abnut and returning to it for shelter. The young derive no nutriment from the parent while contained in the "nursery," other than it may be a mucous secretion.

\section{THE U.S. WEATHER MAPS}

$\mathrm{N}$ this fourth contribution to meteorology, Prof. Loomis discusses certain points of a miscellaneous nature which have been either very slightly or not at all examined in his three previous contributions. The movements of areas of high barometer, which are of so great importance in their relations to weather and climate, have been examined with the result that while the average track of areas of low pressure across the United States is nine degrees to the north of east, the track of areas of high barometer advance toward a point several degrees south of east, and with a velocity somewhat less than the former.

As regards the conditions under which the monthly minima of temperature occur, it is shown that these conditions, viz., winds very light, sky clear, and pressure above its mean height, are substantially the same at Jakutsk, Siberia, as at New Haven. Prof. Loomis is of opinion that it is true universally that periods of unusual cold are generally accompanied by a barometer above the mean, and by a descent of air from the upper regions of the atmosphere. These areas of high barometer have a broader significance than is here implied. It is the still, clear, and dry atmosphere accompanying them, and its relations to terrestrial and solar radiation, which afford the conditions of extreme temperatures. The monthly minima of the cold months of the year and the maxima of the warm months both frequently occur under the conditions afforded by areas of high pressure. On the other hand, in North-western Europe it is often observed that the minima of temperature during the warm months repeatedly occur within areas of low pressure where very light easterly and northerly winds prevail. In discussions of the relations of temperature and pressure, it is seldom kept steadily in mind that the given temperature is merely the temperature observed within a few feet of the earth's surface, which, as regards areas of high pressure, will nearly always mislead if it be used as a basis from which to estimate the temperature of the higher strata vertical to it; the surface temperature being abnormally low in winter from contact with the cooled surface, and in summer abnormally high from contact with the heated surface of the earth.

The examination of storm paths in America, the Atlantic, and Europe is important from the bearing of the subjects un climatology and weather-forecasting. Some interesting results of such an examination are given by Prof. Loomis in the average paths marked on the chart accompanying the paper. The results, however, are not calculated to be practically useful until the average paths be laid down for each month in the year, owing to the very great differences in these paths as regards different months. Thus, in North-western Europe, during the spring months, when east winds are most prevalent in Great Britain, many storm tracks, or the course of barometric depressions, are more southerly, and during the winter months more northerly than that indicated on the chart. If the track of storm-centres in

I Results derived from an examination of the United States Weather Maps and other sources. By Prof. Elias Lo mis, Yale College. Fourth Paper. From the American fournal of Science and Arts, vol. xi, Jan. Paper.
$x 876$. winter getrerally took the line of The Channel, our winters would, on the average, be much more severe than they are, owing to the greater frequency of easterly and northerly winds, which would necessarily follow. But open winters are the rule in these islands, and even as far north as Faroe, where, during winter, southerly and westerly winds largely prefonderate, thus showing that the central rracks of the majority of our winter storms lie to the nor h of Faroe. The exact determination of the average monthly tracks and the more marked deviations from them would throw light on several important questions affecting the climatology of the whole of North-wéstern Europe.

Since the average velocity of storms over the United States as deduced by Prof. Loomis from 485 cases, is twenty-six miles per hour, and over the Atlantic, as deduced from 134 cases, is 19.3 miles per hour; ard the average velocity of European storms as deduced by Prof. Mohn is 26.7 miles per hour, it follows that storms travel less rapidly over the ocean than over continents. If further inquiry confirms this result, we have here a valuable contribution to the theory of storms which will likely lead to a clearer insight into the causes which regulate their rate of propagation over the earth's surface, accelerating it in some cases, and in others retarding it as is frequently seen off the coast of Newfoundland and in the Bay of Biscay.

\section{NATURAL SCIENCE AT CAMBRIDGE}

$7 \mathrm{HE}$ Cambridge Natural Science Tripos has just entered upon a new phase of existence. The recent examination is the first in which a division into two parts, elementary and advanced, is carried out, the former being held in June and the latter in December. Candidates who do rot satisfy the examiners in the first part are not permitted to compete in the second. The final class-list is to be based on the alphabetical principle, but the first class will consist of two divisions, each arranged alphabetically, and the subject or subjects for which a man is placed in the first class are to be indicated, while a special mark will reward superior proficiency. This system removes some of the worst faults of the competitive system, and is of especial benefit to the more able men. One subject will not be pitted against another as regards marks, an accumulation of cramming in several subjects will not serve an inferior man, and clear testimony will be given that a man has a competent knowledge of a subject, or that he is specially proficient in it. With such arrangements, the value of the examination will largely depend upon the wisdom of individual examiners. It will be obvious that there should be at least two examiners in each subject instead of one. Also the pittance they receive should be transformed into fair remuneration, which will, no doubt, be done as soon as the University has more funds at its disposal.

It was to be expected that a new system, by which no man receives any credit in a subject unless he shows satisfactory knowledge of it, and by which the examination is limited to three days, would produce a large number of failures to attain honours. The number of candidates in June was forty-four, a large increase; of these only thirty-one obtained honours, while ten others received the ordinary degree. On scrutinizing the papers, it appears that there is a difficulty in equally adjusting the questions which probably have affected the result. Two questions in each subject, except human anatomy, are given in every paper; one question only is set in human anatomy, which is introduced for the first time. I will quote some of the questions in geology and in physiology, giving fair samples; and it will be plain that they are not equivalent in difficulty, and that students of moderate ability and reading might gain honours by answering the former much more easily than the latter.

"In which of the three great divisions of stratified rocks do fossils of the genera Ichthyosaurus, Phacops, Calamites, Voluta, Terebratula, Ostrea, and Micraster respectively occur?" "Volcanic rocks have been divided into two classes, acidic and basic. Give the name and mineralogical composition of a common rock of each 